Chapter 3

\title{
Herbicide - Soil Interactions, Applied to Maize Crop Under Brazilian Conditions
}

\author{
Flavio Martins Garcia Blanco, \\ Sydnei Dionisio Batista de Almeida and \\ Marcus Barifouse Matallo \\ Additional information is available at the end of the chapter \\ http://dx.doi.org/10.5772/56006
}

\section{Introduction}

This chapter discusses the behavior of herbicides in soil cultivated with maize crop in Brazilian conditions, reporting case studies of herbicide use in different periods, from the earliest to the present time, covering ecotoxicological aspects and reflections on the future of the use of the technology in herbicide-resistant transgenic maize.

Maize (Zea mays L.) is an annual herbaceous plant adapted to the most diverse ecological conditions. It is an economically important crop in tropical, subtropical and temperate climates, as well as in extreme altitudes, allowing its worldwide presence in several continents.

Brazilian maize production is third in the world ranked behind United States and China. Currently, maize is one of the main crops in Brazil with annual grain yields around 57.5 million tons over a large area of production (13.8 million hectares). It is the most consumed cereal in the country under a variety of forms, in nature and processed food. The exportation volume estimate for 2012 is around 14 million tons, which corresponds to US \$2,766 billion income for Brazil [1].

Since the late 1970's maize has been cropped in two distinct yearly periods, in the main Brazilian producing regions: one, called "full-season harvest" corn, sowed in the beginning of the rainy season (September, spring); and the other, called "safrinha" or "little harvest" or fallcorn cropping, sowed in the end of this rainy season (from January to April). Usually, fall corn is sowed after soybeans or common-beans harvest, in the same area where these crops had been previously grown, mainly in the South-Central Brazilian region, involving the States of Paraná, São Paulo, Minas Gerais, Goiás, Mato Grosso and Mato Grosso do Sul. 
Therefore, the maize crop system adopted by Brazilian farmers has evolved from subsistence agriculture to technical agriculture by using improved adapted cultivars for each edaphoclimatic situation and pest management. Currently, maize cropping has shown expressive productivity increases, due to the modern crop production systems and top cultivars obtained via biotechnology. Farm unities with average grain yields above 7 ton per ha are commonly found in those regions.

Despite the fact that fall corn is subjected to higher production risks during the dry season, there is an economical compensation, due to the new market situation (better grain prices) after the full-season harvest offer. Additionally, there are lower production costs because farmers usually use second generation seeds from the hybrid full-season harvest and grow plants only with the residual fertilizers and herbicides, without any extra management.

This type of crop management has contributed to improved corn production in Brazil during the last 30 years: the production area increased from 11.6 to 13 million ha; annual grain yield increased from 19 to 54.1 thousand tons and average productivity from 1.6 to $4.1 \mathrm{~kg} \mathrm{ha}^{-1}$. It is important to emphasize the small production area increase $(10.7 \%)$ compared to the significant increases in grain yields (184\%) and crop productivity (156\%). Evidently, such increases, besides the two harvest seasons per year, were mainly due to research improvements in crop management, plant breeding and biotechnology areas.

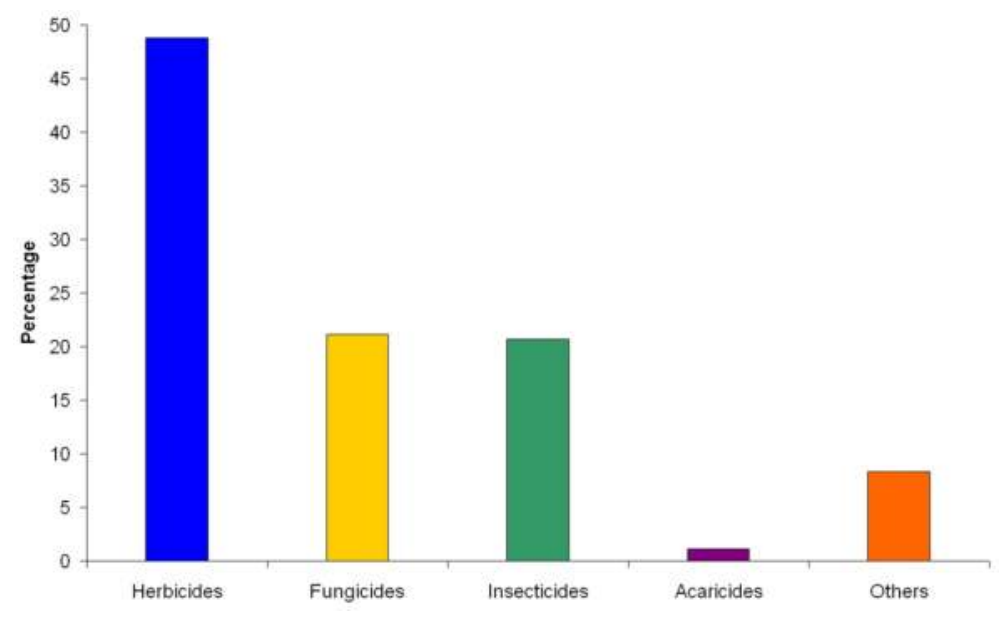

Figure 1. Agricultural pesticides sales (\%) in Brazil (2011). SINDAG [6]

Concerning the research results on maize/ weed cohabitation under Brazilian conditions, classic papers [2-5] have demonstrated yield losses between $22 \%$ and $83 \%$ due to weed competition with the maize crop within a critical period between 15 and 45 days after seedling emergence. There is evidence that weeds prevent maize plants from expressing their maximum production potential, impairing grain yields, even using top maize cultivars obtained through- 
out the highly technical breeding programs associated with biotechnology and modern crop management procedures.

Inasmuch, weed control is the prevalent factor to an economically successful maize crop, and for that, herbicide use is required.

Data from the National Association for Plant Defense (ANDEF) and the National Syndicate of Industrial Products for Agriculture Defense (SINDAG) indicated that Brazil is the world's largest pesticide market, and this industrial business mobilized US \$ 14.1 billion in 2010, divided into the classes described in Figure 1.

The maize crop was the third largest consumer of herbicides in 2011, ranked behind soybeans and sugarcane crops. Therefore, the knowledge on herbicide-soil interaction processes, applied to control weeds, is highly relevant to understanding the herbicide ecotoxicological effects on the maize crop.

\section{Herbicide use in maize crop - A retrospective}

Since the first synthetic herbicide release of 2,4-D, a selective herbicide for Gramineae (Poaceae), in 1946, a revolution has occurred in the field for the crops of the Gramineae family, such as the cereals (wheat, rice, maize, barley and oats).

Concerning the maize crop, [7], cited by [8], reported grain yield increases of 25 thousand tons in a cropping area of 7,000 ha, due only to the use of 2,4-D, just after its release in EUA.

Furthermore, another positive aspect provided by herbicide use in the maize crop was the lower spacing among plant rows adopted, with consequent early shading. The old cultivators that required larger spacing among rows to cultivate the soil and eliminate emerging weeds were not necessary anymore. Therefore, [7] affirmed that only this row spacing change in the field allowed increasing plant population from 30 (in 1950) to 50 thousand plants per hectare (in 1970).

Another factor contributing to farmers' fast adoption of herbicides in maize cropping was the fact that women and children were set free of the hard work of hand-weeding. Weeds were removed by hand among plants within rows because cultivators would remove weeds between rows but not between plants in the row. In hand-weeded maize cropping, a man would spend 12 hours per hectare and the whole crop cycle would require three to five handweeding procedures $[8,9]$. [10] calculated the human workpower necessary just to maintain the same level of annual production at that time and concluded that 18 million men would be required only to hand-weed maize cropping. Considering the work-hour average cost increase from US $\$ 0.50$ (in 1950) to the current US $\$ 7.50$, the choice for herbicide use is almost obligatory economic success in maize.

The advent of s-triazines started in 1952 by researchers from the J. R. Geigy Ltd. Enterprise, in Basel, Swiss: the first patent was obtained in 1954 for the 2-chloro-4,6-bis (alkylamine)-striazines; 2-metoxi and 2-methylthio-4,6 bis (alkylamine)-s-triazines. The triazine selectivity 
description for maize was published in 1955 [11, 12]. The first assays with triazines began in 1952 with the chlorazine molecule. In the following years, so many molecules were synthesized in the same chemical group that a specific symposium was organized in Riverside, California, in 1969 [13].

Since then, herbicide use in the maize increased significantly, because s-triazines were more selective than 2,4-D, which were more phytotoxic to several maize genotypes than s-triazines. Atrazine, specifically, showed low phytotoxicity to maize plants and could also control some dicotyledonous weeds, a distinct property not shown by 2,4-D that is a specific graminicide herbicide. Therefore, important competitive weeds to the maize crop could then be controlled, such as Bidens pilosa, Emilia sonchifolia, Amaranthus sp, Euphorbia heterophylla, Portulaca oleraceae, and Sonchus oleraceae, representing an advance in weed control management in maize.

Extensive literature concerning s-triazines interactions in the soil can be found because they are among the soil applied herbicides most used worldwide, making it difficult to present a complete review on this subject. A significant number of international reports about atrazine and simazine are available about the most used triazines in maize, but little literature on the environmental toxicology area for Brazilian conditions is available.

Among the herbicides of the s-triazine group used in maize is atrazine; since its release up to now, it has been considered an excellent herbicide due to its selectivity, range of weed control and safety, not causing phytotoxicity for successive crops. At present, it is estimated that $75 \%$ of maize-cropped area in the USA is treated with atrazine.

Atrazine $\left(\mathrm{C}_{8} \mathrm{H}_{14} \mathrm{ClN}_{5}\right)$ properties are: chemical name (IUPAC) 6-chloro- $\mathrm{N}^{2}$-ethyl- $\mathrm{N}^{4}$-isopropyl-1,3,5-triazine-2,4-diamine; fusion point $=175^{\circ} \mathrm{C}$; solubility in $\mathrm{H}_{2} \mathrm{O}_{\left(20^{\circ}\right)}=33 \mathrm{mg} \mathrm{kg}^{-1}$; vapor pressure $=3.010^{-7} ; \mathrm{pK}_{\left(21^{9}\right)}=1.68$ and $\log \operatorname{Kow}_{\left(25^{\circ}\right)}=2.61$, [12].

In Brazil, atrazine is largely used and registered for pineapple, sugarcane, pine, rubber-tree, sorghum and maize.

Atrazine is mainly taken up by roots and also through leaves of plants. When absorbed by roots, it is rapidly transported upwards via xylem and accumulated in the meristems; its movement in the phloem is restricted. Atrazine functions through photosynthesis inhibition by impairing the Hill reaction in the photosystem II, leading to death of susceptible plants. In tolerant plants, like maize and sorghum, atrazine is bound to glutathione (GHS), blocking the atrazine molecule herbicide action [14].

At first, atrazine and other s-triazines were recommended only as pre-emergent herbicides, that is, applied directly on the soil or incorporated just after sowing. However, in the early 1990's, farmers faced climate difficulties that impeded application as recommended, because the pre-emergent application would require a dry period without rain just after sowing to put the implements in the field; in many cases, the dry period would not occur and when the climate conditions were favorable, both the maize seeds and weeds had already emerged their second leaves, characteristic of the first emergence flow. Then, farmers did not have other options than that of applying the herbicide over the plants in the initial stage of development, characterizing a post-emergent herbicide application. From then on and to date, atrazine has 
been observed to efficiently control weeds and not cause any toxicity to maize plants, allowing its recommendation also as a post-emergent herbicide.

This occurred at the same time that new post-emergent herbicides were released for maize including: nicosulfuron, isoxaflutole, foramsulfuron + iodosulfuron-methyl, mesotrione and tembotrione. The main advantage of the post-emergent procedure is to better adjust the herbicide dose to control the emergent weed flora, avoiding excessive rates, saving money and decreasing environmental impact. However, there are toxicity risks mainly concerning maize or other more susceptible crops in succession to maize due to residual herbicide effects in the soil. Since the herbicides are indicated for post-emergent application and they are applied over plants, at first, it might erroneously suggest that such chemical products do not persist in the soil or show low persistence.

It is important to highlight that many of those new herbicides have been indicated for agricultural use as components of mixtures with atrazine, similar to the usual recommendation for metolachlor (chloroacetamides group). The herbicide action of atrazine + metolachlor mixture consists of the inhibition of weed cellular division mainly in plants from Poaceae (Gramineae group), complementing the broadleaf weed atrazine action (dicotyledonous plants). Therefore, this herbicide mixture has a wider range of action over weed species which explains its commercial success; up to now, it is considered the best standard herbicide mixture for maize.

Now, research work must focus on these two herbicides in studies concerning the herbicidesoil interactions, applied to maize, since herbicide residues might persist in soils for longer periods than expected, causing phytotoxicity to the next season crop in succession or rotation practices. The knowledge on herbicide persistence in soils is critically important for the adequate use of such products in sustainable environmental systems.

\section{Herbicide interaction in soils}

In agricultural systems, the soil represents the final destination of large numbers of herbicides applied directly on the soil or over the plant shoots [15].

Herbicides interact with the environment throughout three main routes: (1) physical processes such as soil desorption, volatilization, lixiviation (by water) and erosion together with soil (by wind and water); (2) chemical processes such as photodecomposition, adsorption, reaction with soil components; and (3) biological processes such as molecule decomposition by microorganisms and absorption by plants $[16,17]$.

According to [18-22], all those processes are dependent on the soil chemical and physical characteristics (soil texture, structure, colloid nature and concentration, $\mathrm{pH}$, etc.) and climatic conditions, particularly, the soil temperature and moisture. On the other hand, the herbicide chemical characteristics depend on the molecular structure, ionization, water solubility, liposolubility, polarization and volatization. 
Different external factors exert important roles on herbicide-soil interactions, such as the herbicide formula, rate and mode of application, which are illustrated in Figure 2.

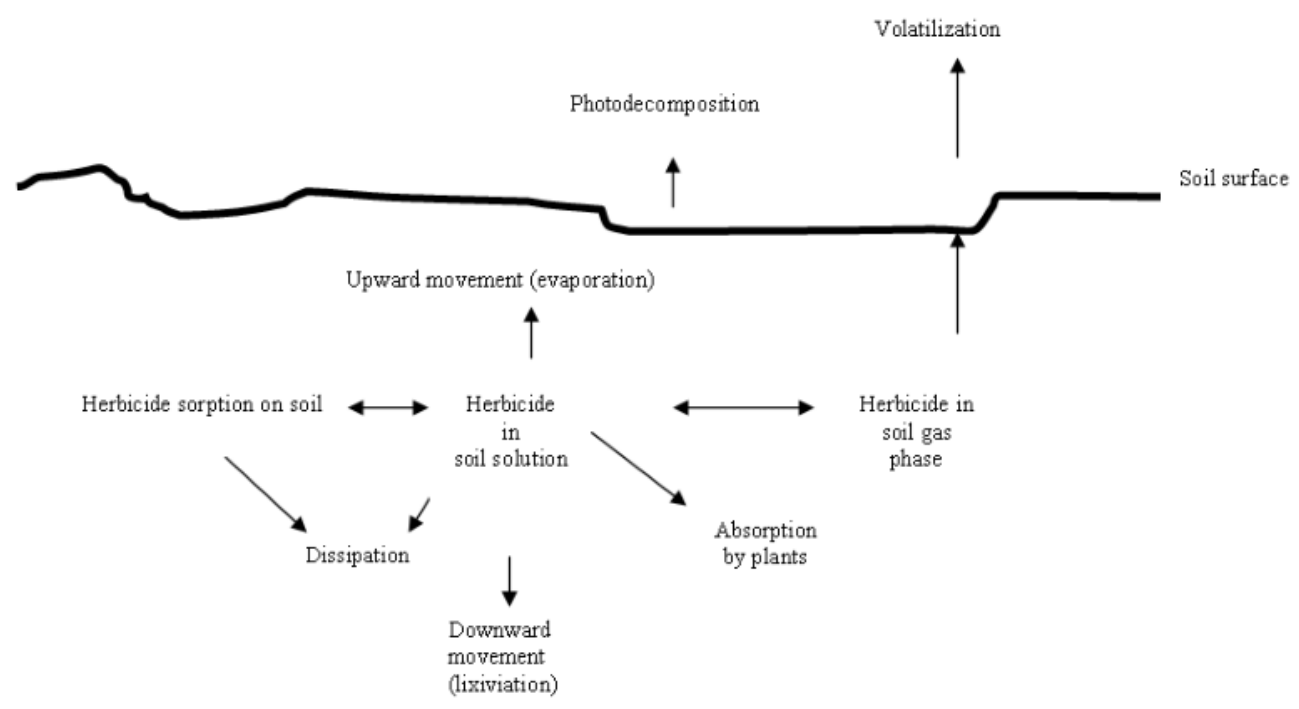

Figure 2. Diagram of the main herbicide-soil interaction processes, adapted from [20].

The processes of soil colloid adsorption-desorption of herbicide molecules greatly influence herbicide movement and transformation in the environment.

\section{Soil sorption (adsorption) and desorption of herbicide molecules}

The soil adsorption process is understood as the adherence of a molecule, an ion or other particle on the soil surface, as a result of the interaction between both the adsorbing (clay, organic matter) and adsorbed surfaces' field strengths (in this case, the herbicide). Herbicide particles may also be absorbed (taken up) by soil colloids. [23], discussed about the difficulty in differentiating between the absorption and adsorption phenomena, suggesting the term "sorption" to express both processes.

Soil sorption is generally a reversible phenomenon (sorption/desorption) and an equilibrium is reached between the adsorbed (sorbed) herbicide concentration on clay/organic matter and the herbicide concentration in the soil solution [24,25]. The soil sorption is generally a physical process in which attraction forces are involved: such as the van der Waals strengths, bipolar particle interactions, hydrogen bridges and hydrophobic binds. When soil sorption is resultant from chemical processes, an irreversible chemical reaction (herbicide-soil colloid interaction) might occur and a third compound or a stable complex molecule is formed. Soil sorption is a 
fundamental factor in environmental toxicological studies, because it is determinant to other processes like lixiviation and microbial decomposition [26, 27].

Soil sorption is affected by the involved molecule size. [24] demonstrated that large organic molecules, like herbicides, when adsorbed in montmorillonite clay type, can hardly be substituted by small ions. However, the authors affirmed that the most influential property of clay is the charge type. A stronger electrical charge is generated from dissociation and a weaker charge is resultant from a non-uniform electron distribution on the molecule surface, causing weak polarity.

Briggs $[18,19]$, affirmed that the extension and intensity of processes involved in the sorption/ desorption phenomena are greatly dependent on the herbicide molecular properties and soil temperature and moisture. Similarly, [15] cited the importance of herbicide physical-chemical properties, as well as of soil $\mathrm{pH}$, soil colloid type and soil cation retention.

Velini [22], evidenced that the knowledge on how much the sorption process influences the herbicide sorption on soil colloids is fundamental to define the herbicide application rate to efficiently control weeds.

According to [28], the sorption/desorption processes are highly influenced by the soil colloid type because the larger the specific surface (organic matter, 2:1 clay type), the larger the sorption on soil colloid. Soil moisture also significantly affects the process, once the higher the moisture the lower the sorption. This is due to the fact that $\mathrm{H}^{+}$ions, with concentrations dependent on the soil moisture content, compete with the herbicide molecules for the sorption sites at the soil colloids' surface. Therefore, higher herbicide sorption occurs under a water deficit.

The acidic and alkaline compounds' ionization is dependent on the soil $\mathrm{pH}$ and herbicide $\mathrm{pK}$. In the case of atrazine, $\mathrm{pK}_{\left(21^{\circ}\right)}=1.68$; and under Brazilian soil $\mathrm{pH}$ conditions ( $\left.\mathrm{pH}>5.5\right)$, most molecules would be in the molecular form ${ }^{1}$, subject to the non-ionic sorption processes, such as hydrogen bridges and van der Waals forces.

In accordance [50], the lack of knowledge about the sorption/desorption phenomena is not surprising because the soil is a highly complex biological and chemical medium, making it difficult to completely understand the interdependent relationships and interactions among the several components involved which certainly affect the herbicide sorption/desorption processes in the soil.

\section{Herbicide movement in the soil}

Pre-emergent herbicides are expected to present a certain movement in the soil and to be taken up by weed seedling roots because such movement provides an important soil surface

$1 \%$ ionization $($ base $)=\frac{100}{1+\operatorname{antilog}(p H-p K)}$ 
incorporation, allowing a better herbicide contact with greater number of weed seeds or seedlings and maximizing weed control.

Herbicides applied to the soil might move in all directions and phases - gaseous or liquid phases - in areas exposed to intense winds during specific year periods, which could transport considerable herbicide amounts [28], but the vertical descendent route is the most significant movement, characterizing herbicide lixiviation [29, 15].

The herbicide lixiviation in soils is a relevant factor affecting herbicide persistence in the environment. Herbicide lixiviation is dependent on several factors related to the herbicide molecule properties (as intrinsic molecule unity - volatilization, ionization capacity, water solubility, molecular size and weight and lipophilicity) and edaphoclimatic factors (soil type, organic matter content, relief, rainfall and temperature), as well as the herbicide application method. All these factors will determine an herbicide immobilization rate by soil sorption and will influence the herbicide lixiviation. When the herbicide is dragged into deeper soil layers by lixiviation, it persists for longer periods in the environment due to the absence or lower number of microorganisms responsible for the molecule decomposition [30].

The knowledge on herbicide movement routes in soils is essential to a better herbicide/weed management (dose and application method) as well as to understand the potential contamination risks to the environment. The possible herbicide routes that might severely contaminate environment resources include lixiviation to underground waters, superficial molecular movement in solution or suspension (erosion) to water flows, volatilization (air contamination), and removal by live organisms [30].

The higher the herbicide lipophilicity, the higher the tendency to be sorbed on soil colloids, and consequently, lower herbicide lixiviation would be expected. On the other hand, high hydrophilic herbicides would be expected to show lower soil sorption and higher lixiviation rates.

Besides the herbicide vertical movement in the soil profile being an important indicator of its potential contamination risk to underground water and deeper layers, it is also an indicator of herbicide persistence and potential contamination risks to plants with deeper root systems.

Herbicide soil persistence can be determined by biological methods (using bio-indicators) and by chemical or radiometric methods. Both methodologies have advantages and disadvantages and allow assessing the period of herbicide presence in the soil within the detection limits of each method used [31].

Several research works of environment monitoring for potentially toxic residues have been carried out during the last decades, mainly in developed countries. For instance, [32] reported the soil analysis results of 130 different pesticide and herbicide residues applied to agricultural soils in annual crops of 43 USA states. Among the 130 chemical products, only 24 were found in soils during the harvest period: 6 herbicides, 5 phosphorous pesticides, 11 chlorinated pesticides and 2 arsenium pesticides. Among the herbicides, atrazine and simazine, both from the triazine group, persisted in the soil for periods of 12 and 10 months, respectively. [33], when monitoring more than 2200 wells in areas of irrigated maize, detected the presence of several herbicides, such as atrazine, simazine, propazine, prometon and ametrine, and also traces of metolachlor in several well-water samplings. 
In Brazil, significant amounts of atrazine and simazine residues were detected in artesian wellwaters in the recharge area of Guarani aquifer, an important underwater natural resource [34].

Almeida [35], carried out detailed s-triazine sorption/ desorption studies on different soils from the region of Ubatuba municipal district, State of São Paulo, Brazil. The authors reported that potential herbicide lixiviation and/or superficial runoff would depend on the intrinsic soil characteristics and that the herbicide recommendation must be supported and evaluated based on such soil attributes. Furthermore, the authors observed high s-triazine sorption and consequently lower lixiviation potential in high organic-C content soils; and low herbicide sorption in low C-content soils, favoring desorption and increasing the potential risk of subsoil contamination. They concluded that the soil organic-C content is directly related to the striazine sorption and it might be an important indicator of herbicide lixiviation potential, corroborating the results observed in [36].

\section{Determination of herbicide persistence and lixiviation: Simazine, atrazine and metolachlor}

Blanco [37], determined herbicide persistence and lixiviation up to $50 \mathrm{~cm}$ soil depth, using gaschromatography, in a field experiment with simazine applied as a pre-emergent herbicide in maize at the rate of $3 \mathrm{~kg} \mathrm{ha}^{-1}$ (a.i. = active ingredient), in the State of São Paulo, Brazil. The results obtained are described as follows:

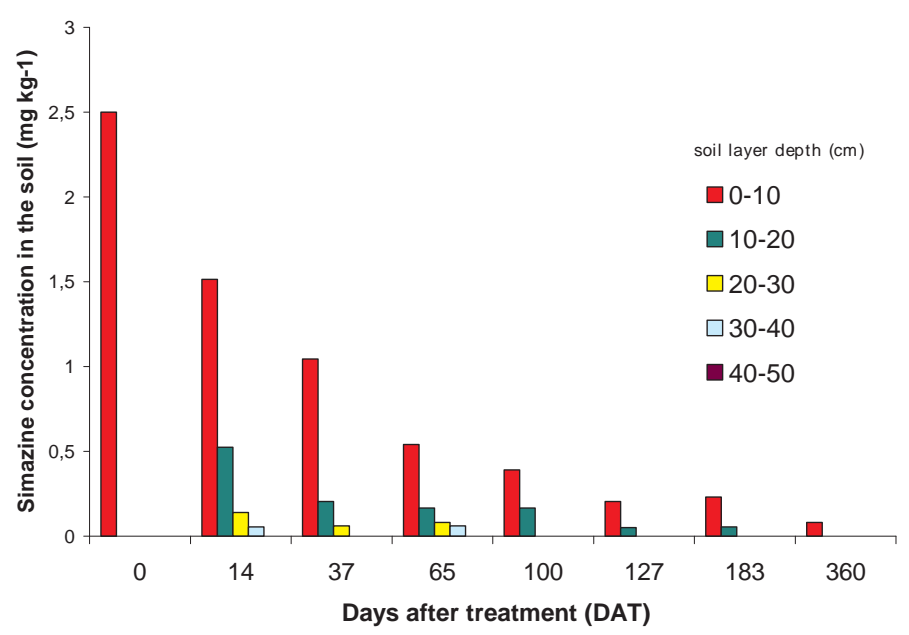

Figure 3. Simazine residue means determined in several soil depth samples (layers from 0-10 until 40-50 cm), collected in different sampling dates [37].

The highest simazine concentration was found in the 0-10 cm superficial soil layer (Figure 3) and decreasing simazine concentrations were found in deeper layers $(30-40 \mathrm{~cm}), 14$ until 65 
days after treatment (DAT), but at levels near the method detection limit $\left(0.05 \mathrm{mg} \cdot \mathrm{kg}^{-1}\right)$. No simazine residue was found in the 20-30 and 30-40 cm layers, 100 DAT. Simazine persisted in the $0-10 \mathrm{~cm}$ layer until 360 DAT in concentrations near the method detection limit. At 10-20 cm layer, simazine persisted until 100 DAT, and afterwards (127 and 183 DAT), only residues near the detection limit were found. The simazine persistence curve was obtained by regression analysis, considering the total residue data in the soil profile $(0-50 \mathrm{~cm}$ depth, Figure 4$)$.

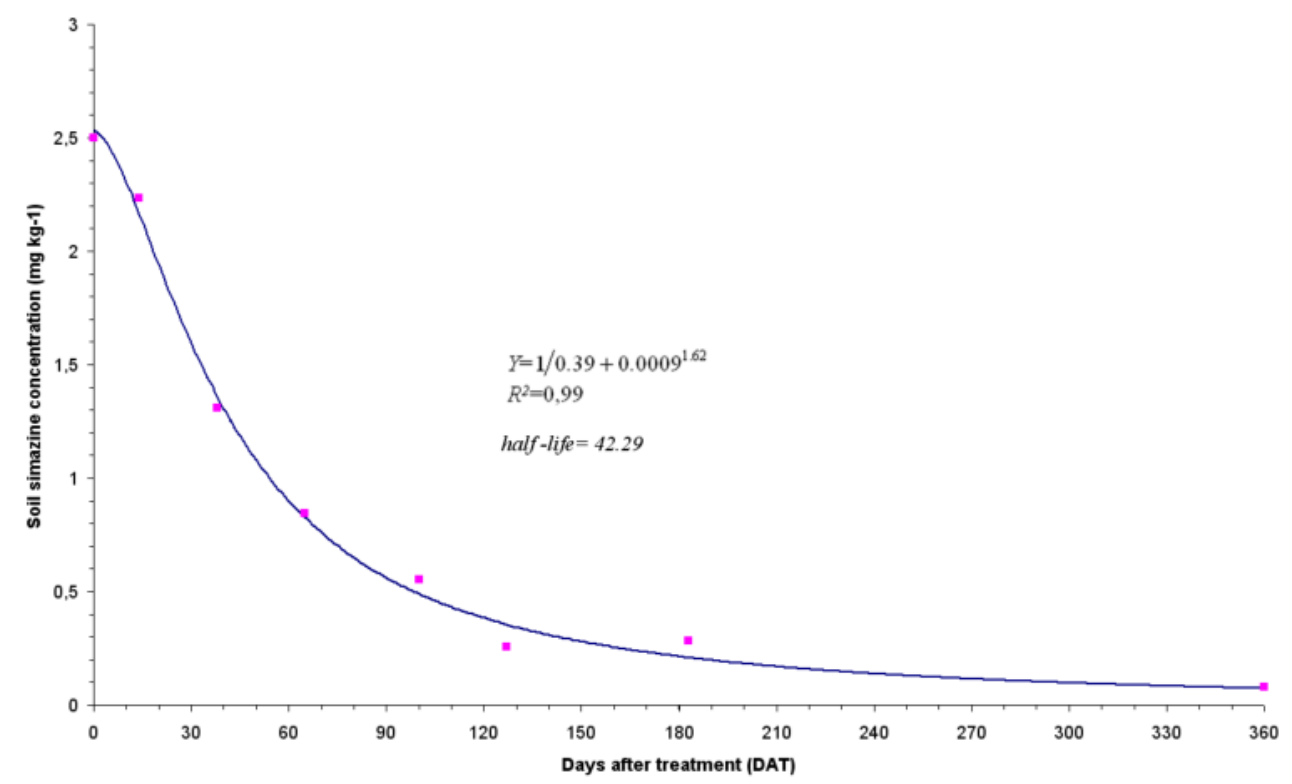

Figure 4. Simazine persistence curve determined until 360 days after treatment, applied as pre-emergent herbicide in maize crop [37].

The persistence curve (Figure 4) fitted an exponential equation, showing a fast decrease of soil simazine concentration until $120 \mathrm{DAT}$; and afterwards, a slower decreasing slope was observed until 360 DAT. These results might be explained by the rainfall distribution (Figure 3), because a dry period occurred between 112 and 215 DAT, causing adverse conditions to microbial development with consequent increased herbicide molecule adsorption and decreased availability/ dissipation. After 230 days, frequent rainfalls and high soil moisture favored dissipation by biotic agents and soil desorption, once the higher the soil moisture the higher molecule availability and dissipation; other dissipation types might also occur.

Researchers tended to confirm these results, that is, under different Brazilian conditions, simazine remained in the superficial soil layer [38 - 44]. Nevertheless, such affirmations must be supported with information on soil conditions and the triazine group that the studied molecule belongs to as well as on the field experiment local climate where the results were obtained. 


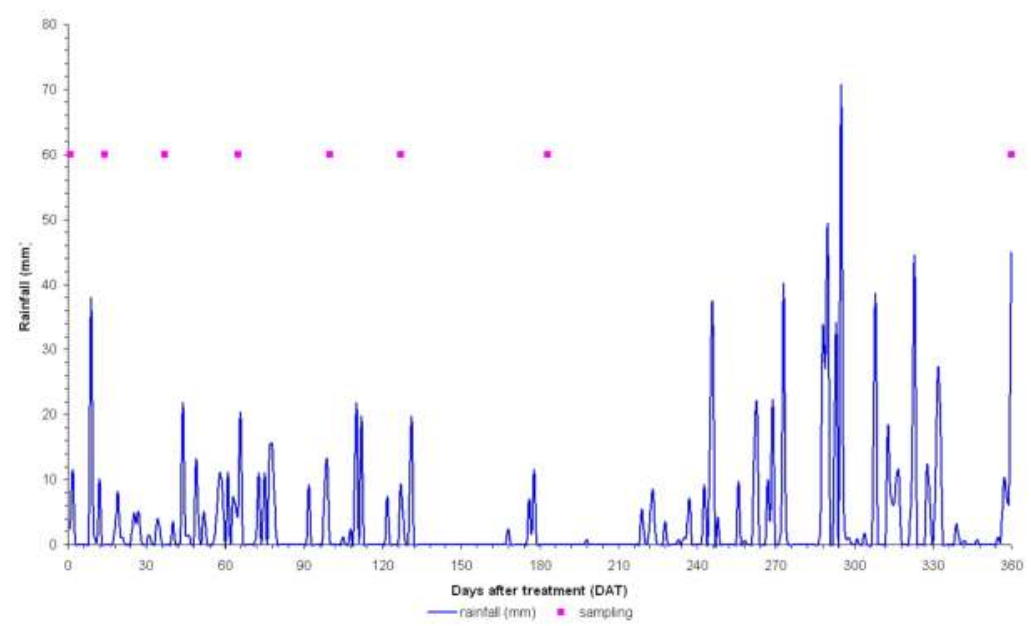

Figure 5. Daily rainfall occurred during the experiment period, January $14^{\text {th }}, 1992$ to January $8^{\text {th }}, 1993,[37]$.

Dawson [41], found simazine residues one year after the last annual application (of a total of six applications) in the 10-20 cm depth layer; Albers and Homburg cited by [44], also found simazine movement below $15 \mathrm{~cm}$ depth for a six-month period in several soil types.

In this experiment, [37] observed that the soil solution $\mathrm{pH}$ varied from 6.8 to 5.3 in soil samples; and the simazine $\mathrm{pK}_{\left(21^{\circ} \mathrm{C}\right)}=1.7$ indicated that, under these conditions and despite simazine being a weak base, most herbicide molecules would be in the molecular form (only $0.006 \%$ would be ionized). According to [45, 46], simazine presents $\log$ Kow $=1.51$ characterizing its lipophilic property, and increasing the chances of herbicide molecule sorption by soil colloids.

Gast [13] cited by [30], demonstrated that simazine mobility is affected by soil organic matter (OM). In soil columns with 27 to $30 \%$ of OM, the herbicide did not percolate, but in sandy soils, herbicide lixiviation occurred until $17.50 \mathrm{~cm}$ depth. In field experiments, [39] found higher simazine concentrations below $30 \mathrm{~cm}$ than in the first $15 \mathrm{~cm}$ above, 16 months after application. These authors' results were related with the low soil OM (0-10 $\mathrm{cm}$ layer $=0.60 \% \mathrm{OM}$; and $40-50 \mathrm{~cm}$ layer $=0.19 \% \mathrm{OM})$ what might explain the simazine lixiviation until deeper soil layers $(40 \mathrm{~cm})$.

In another research, following the same procedures, [47] evaluated the atrazine and metolachlor herbicide persistence and lixiviation, applied pre-emergence to maize, as the commercial product Primestra at the rate of 8.0 L.ha ${ }^{-1}$ (1600 g ai atrazine $+2400 \mathrm{~g}$ ai metolachlor). The highest atrazine herbicide concentration was found restricted to the superficial soil layer $(0-10 \mathrm{~cm})$ (Figure 6). In the 10-20 cm depth layer, the herbicide was found only 15 DAT; and no residue was found in deeper layers until 380 DAT. Atrazine persistence was detected until 184 DAT.

The atrazine persistence curve fitted an exponential equation obtained by regression analysis of the total residue data from 0 to $50 \mathrm{~cm}$ depth layers (Figure 7). The initial atrazine residue level was depleted very rapidly from soil and tended to stabilize 100 DAT, remaining constant 


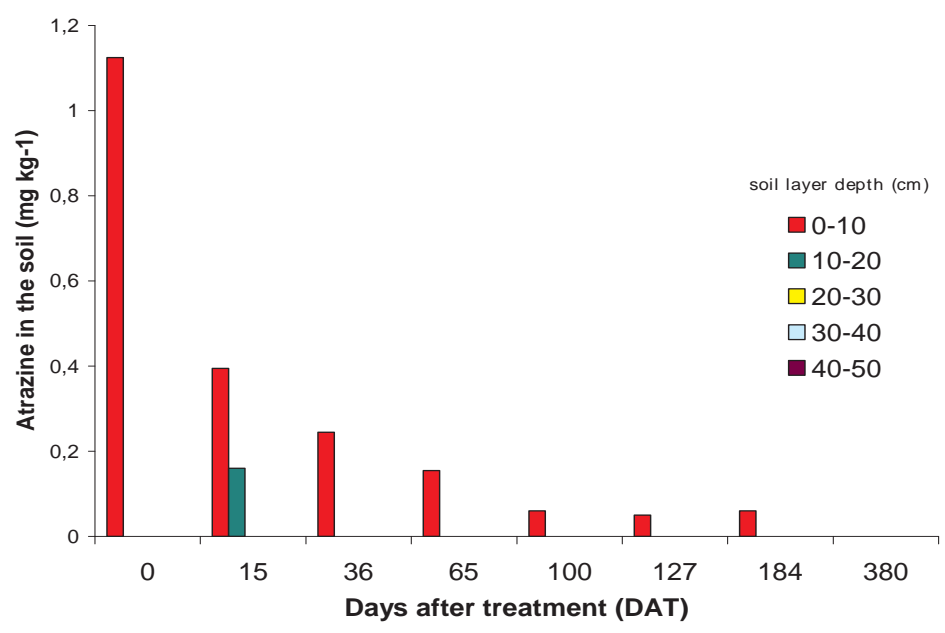

Figure 6. Average atrazine values found in different soil depth layers and sampling dates, in maize crop [47].

until 184 DAT. Afterwards, it tended to zero, and it was not detected at any other sampling dates.

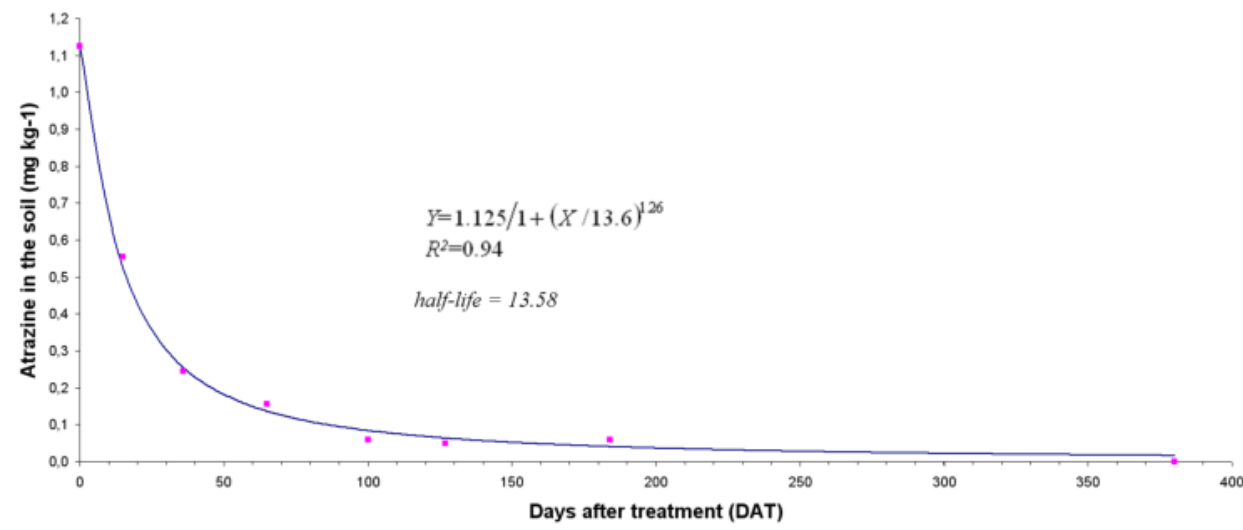

Figure 7. Atrazine herbicide persistence, applied in pre-emergence to maize crop [47].

The metolachlor persistence curve (Figure 8) was similar to the atrazine curve, showing higher residue concentration in the $0-10 \mathrm{~cm}$ depth layer. However, metolachlor persistence differed from atrazine due to the fact that it was detected until $380 \mathrm{DAT}$, and also, because metolachlor lixiviated until 20-30 cm and 10-20 cm depth, 15 and 100 DAT, respectively. 


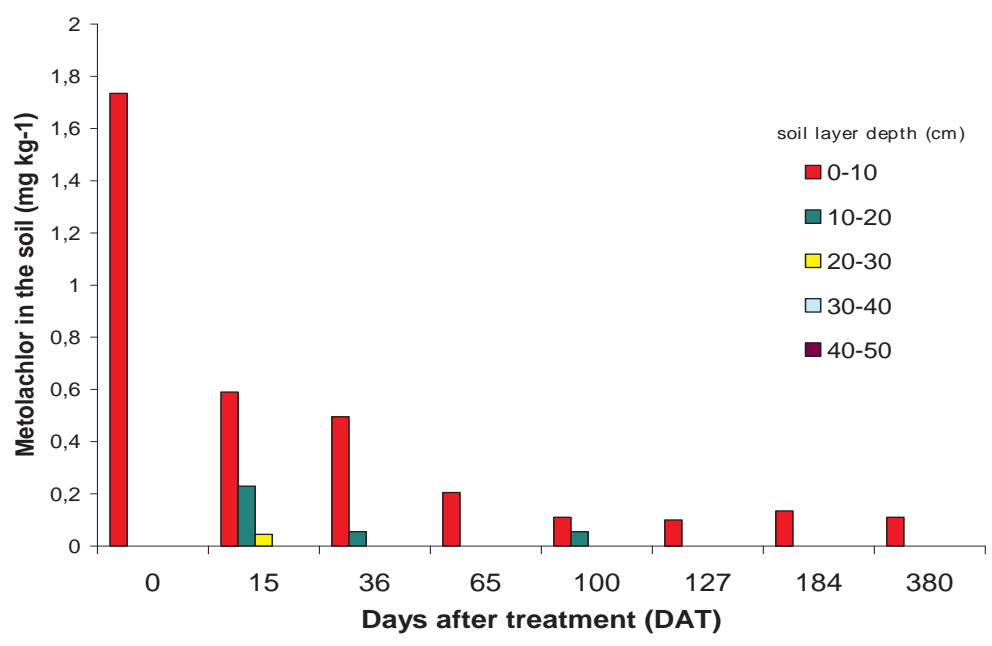

Figure 8. Average metolachlor values found in different soil depth layers and sampling dates, in maize crop [47].

Regression analysis was applied to the total residue data up to the $50 \mathrm{~cm}$ depth and the persistence curve fitted an exponential equation (Figure 9).



Figure 9. Metolachlor herbicide persistence, applied pre-emergence to maize [47].

A rapid decrease of metolachlor residue concentrations were observed until 100 DAT (0.20 mg $\left.\mathrm{kg}^{-1}\right)$, and afterwards it tended to stabilize reaching the method detection limit $\left(0.05 \mathrm{mg} \mathrm{kg}^{-1}\right)$ 380 DAT.

The rainfall regime is presented in Figure 10. In the experiment beginning, rainfalls were not abundant favoring metolachlor sorption and immobilization on soil colloids, and thus, 
reducing the dissipation factors. The frequent and abundant rainfalls observed 220 DAT favored metolachlor desorption; its molecules were released in the soil solution and entered through dissipation processes and, consequently, the metolachlor concentration was fast depleted from the soil solution.

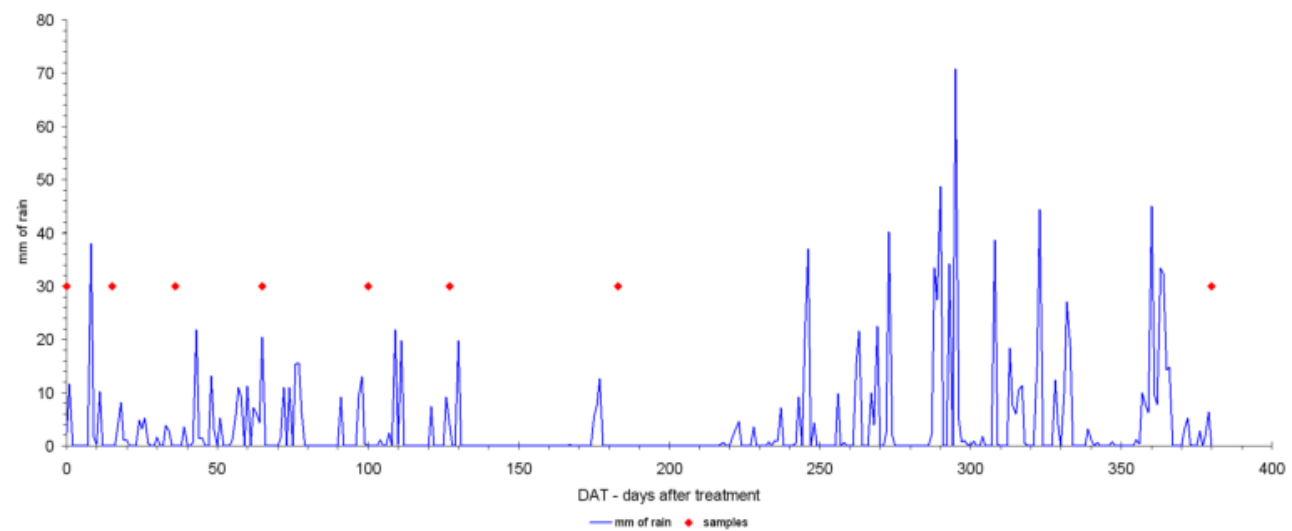

Figure 10. Daily rainfall occurred during the experiment period, January $14^{\text {th }}, 1992$ to January $20^{\text {th }}, 1993$ [47].

Blanco et. al [37, 47] carried out field experiments in the same period and edaphoclimatic conditions, allowing the comparison between simazine and metolachlor results: metolachlor presented higher persistence (380 DAT) than atrazine (184 DAT), and this latter showed lesser lixiviation (until $20 \mathrm{~cm}$ depth), once metolachlor and simazine lixiviated until 30 and $40 \mathrm{~cm}$ depth, respectively.

From these results it might also be inferred that when these herbicides are sequentially used in successive crops, undesirable product residue amount might accumulate in the soil. For instance, at maize harvest (100-120 days after sowing), significant herbicide residual concentrations might be left until the next crop sowing date, causing damage to the environment and plants as well as promoting plant resistance to herbicides.

In the research described in item [56] used bioassay methods to evaluate the atrazine persistence applied as post-emergent herbicide in maize at rates of 1000 and $2000 \mathrm{~g} \mathrm{ha}^{-1}$ and observed that persistence ended $56 \mathrm{DAT}$, independently of the atrazine rate. Although comparing different methods, the above result was similar to the one presented in Figure 7, where the end of atrazine persistence was found $83 \mathrm{DAT}$, determined by gas-chromatography.

The edaphoclimatic condition effects on herbicide persistence in soils are well-known. Soil and climate conditions may directly alter the herbicide persistence or impair different degradation routes in many ways, whatever biotic (caused by microorganisms) or abiotic processes occur. Little Brazilian literature is found concerning the environmental impact caused by herbicide persistence, dissipation and lixiviation, when compared to foreign literature, especially about 
atrazine that is largely studied in foreign countries. However, data from foreign countries cannot be extrapolated to Brazilian soil and climate conditions.

For example, [48] studied atrazine dissipation in a clayey loam type soil cropped with maize in England (with atrazine rates of 1.10 and $3.30 \mathrm{~kg} \mathrm{ha}^{-1}$ ) and observed an exponential atrazine dissipation, but longer half-life (3 to 3.6 months), much different from the half-life found by [45] under Brazilian conditions for the same herbicide (13.58 days) (Figure 7).

It is described in the paper [49], studying atrazine degradation in field soils of Spain, found a half-life of 30 days, and demonstrated the microbial and chemical nature of atrazine degradation, corroborating the results reported by [11]. The latter authors affirmed there is a strong relationship between s-triazines' inactivation and optimal conditions for microbial community growth. Nevertheless, several soil factors such as increasing soil temperature and moisture, low $\mathrm{pH}$ and high soil organic matter content usually favor triazine chemical degradation by hydrolysis [11].

The foreign literature has cited metolachlor (acetanilide group) as the most persistent herbicide in soils, superior to propachlor and alachlor. [50] and [28] reported metalochlor half-life of 33 and 15 days for sandy loam soils and clayey loam soils, respectively, both soils under $80 \%$ of water field capacity. Results reported in [47], found similar metalochlor half-life (11.16 days) in clayey loam soil (Figure 9).

Many authors reported metolachlor degradation as an essentially microbial degradation type [51-54]; the soil organic matter is preponderant to metolachlor dissipation because this herbicide shows lipophilic molecule characteristics $(\log$ Kow $>3)$ and it is strongly adsorbed in high OM-soils $[45,55]$; thus, explaining the metalochlor lixiviation observed in low OM-soil until $30 \mathrm{~cm}$ depth reported by [47] (Figure 8).

When herbicide persistence is determined through biological methods, a specific susceptible test plant is used as an indicator. For that, the test plant is submitted to herbicide residue and the time period of herbicide bioactivity is evaluated as well as its molecule impact on the environment. Since test plants are more susceptible than crop plants, it is possible to estimate the time period that an herbicide is potentially active in the soil to cause damage to susceptible crop plants in succession to the previously treated crop [31].

\section{Determination of mesotrione and tembotrione herbicide persistence in soils}

Results described in [56], evaluated the tembotrione and mesotrione persistences, applied at two rates, as post-emergent herbicides to maize under different planting systems, using beetroot (Beta vulgaris, Early Wonder cv) as a test plant. Soil samples from the field experiment were collected at predetermined dates and used to grow potted test plants under growthchamber conditions (Conviron phytotron, PVG386 model). After 14 days, plants were cut above the soil and evaluated for shoot fresh matter. The treatment means with and without (control) herbicide were compared by $t$ test at $0.05\left(t_{5 \%}\right)$. 
In this way, bioassays with test plants were used to determine tembotrione and mesotrione soil persistence during four consecutive field experiments.

Tembotrione (2-\{2-chloro-4-mesil-3-[(2,2,2-trifluoroetoxi) metil]benzoil\} ciclohexane -1,3dione), solubility $=28 \mathrm{mg} \mathrm{L}^{-1}, \mathrm{pKa}=4.22$, and mesotrione (2-(4-mesyl-2-nitrobenzoyl)cyclohexane-1,3-dione), solubility $=168.7 \mathrm{mg} \mathrm{L}^{-1}, \mathrm{pKa}=3.07$, is an herbicide from the triketone group. The herbicide mechanism of action is the inhibition of the hydroxyphenylpyruvate-dioxygenase enzyme impairing carotenoids biosynthesis and destroying cellular membranes, leading to the death of susceptible plants.

In Brazil, they are indicated as post-emergent herbicides in both maize growth periods (fullseason harvest and little harvest or "safrinha" corn).

\section{Mesotrione and tembotrione herbicide persistence determination in "safrinha" corn}

The bioassay was carried out in potted test plants grown in medium texture soil ( $\mathrm{pH} 4.9$ and $3 \% \mathrm{OM}$ ), treated with two mesotrione rates (192 and $384 \mathrm{~g} \mathrm{ha}^{-1}$ ). The results (Figure 9) showed that beetroot plants were able to grow and develop only after the sixth soil sampling (84 DAT), with the lower herbicide rate. With the double rate, the test plants grew only 114 DAT. From then on, plants showed increasing shoot fresh matter yields in both treatments, until the moment when no significant differences were found between the control and treated plants (H0 - null hypothesis accepted). Therefore, the end of mesotrione persistence was determined 114 DAT and 177 DAT for the first and second rates (192 and $384 \mathrm{~g} \mathrm{ha}^{-1}$ ), respectively.

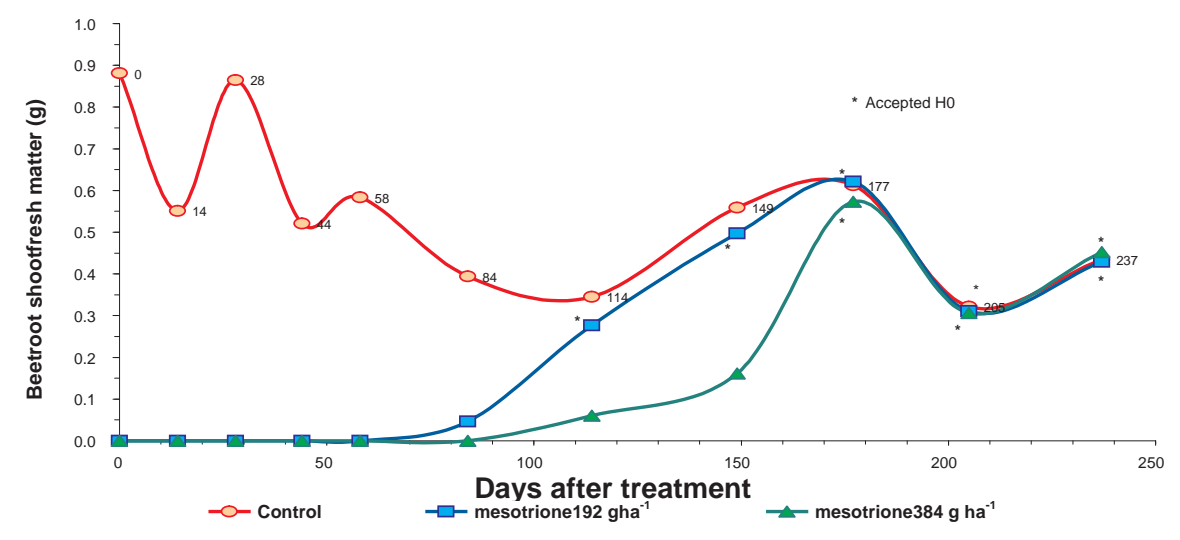

Figure 11. Residual effects of mesotrione herbicides on potted beetroot plants, used as susceptible test plants, grown under growth-chamber conditions. Data is referred to shoot fresh matter $(\mathrm{g})$ and means were compared by $\mathrm{t}$ test (0.05). [56]. 
The rainfall regime during the field experiment is shown in Figure 12. In the beginning of the experiment less frequent and little rainfall occurred. Despite the considerable $140 \mathrm{~mm}$ rainfall peak volume between 30 and 40 DAT, the favorable situation did not persist and it was followed by a 130 day-dry period. This fact favored herbicide sorption to soil colloids making it unavailable in the soil solution and restricting the dissipation processes.

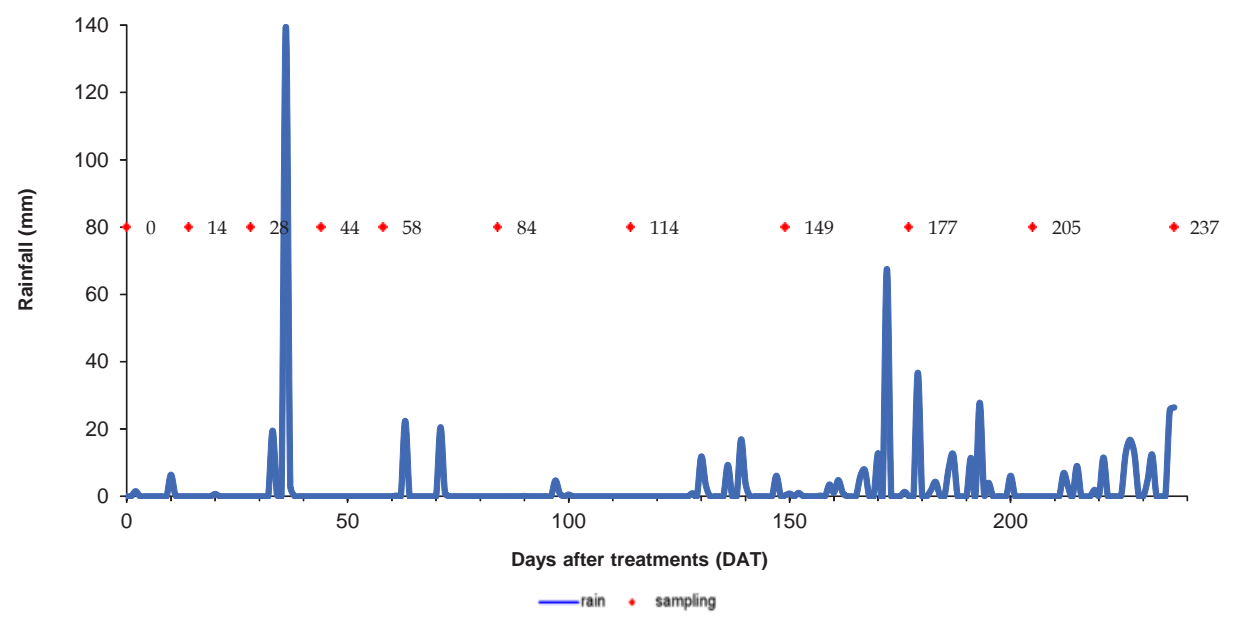

Figure 12. Rainfall distribution observed during the experiment period described in Figure 11. [56]

Such rainfall distribution explained the slow mesotrione dissipation during the initial dry period because the herbicide final persistence was only found 114 DAT, for the lower treatment rate. When rainfall started 130 DAT, mesotrione desorption was favored, increasing its availability, followed by its depletion from the soil solution through dissipation processes. At this point, the test plants were not affected anymore (177 DAT), indicating the mesotrione persistence end for the second rate $\left(384 \mathrm{~g} \mathrm{ha}^{-1}\right)$.

The results obtained with test plants grown in soil samples with residual tembotrione from the "safrinha" field corn crop (medium texture soil, pH 5.1 and $\mathrm{OM}=1.1 \%$ ) are presented in Figure 13.

The beetroot shoot fresh matter for different soil sampling periods (Figure 13) showed that these susceptible plants started to grow after the third soil sampling (32 DAT). This means that the null hypothesis $(\mathrm{H} 0)$ for the rate of $100.8 \mathrm{~g} \mathrm{ha}^{-1}$ was rejected at this time (significant differences between treatment and control means were found by t test 0.05 ). The null hypothesis (H0) was only accepted between 55 and 120 DAT, meaning that no significant differences in plant growth among treatments and control were observed at this time, and that the tembotrione persistence ended 55 DAT for the first rate (100.8 $\left.\mathrm{g} \mathrm{ha}^{-1}\right)$. For the second rate (201.6 $\left.\mathrm{g} \mathrm{ha}^{-1}\right)$, the test plant growth occurred between 75 and 120 DAT, evidencing the end of tembotrione persistence 75 DAT. 


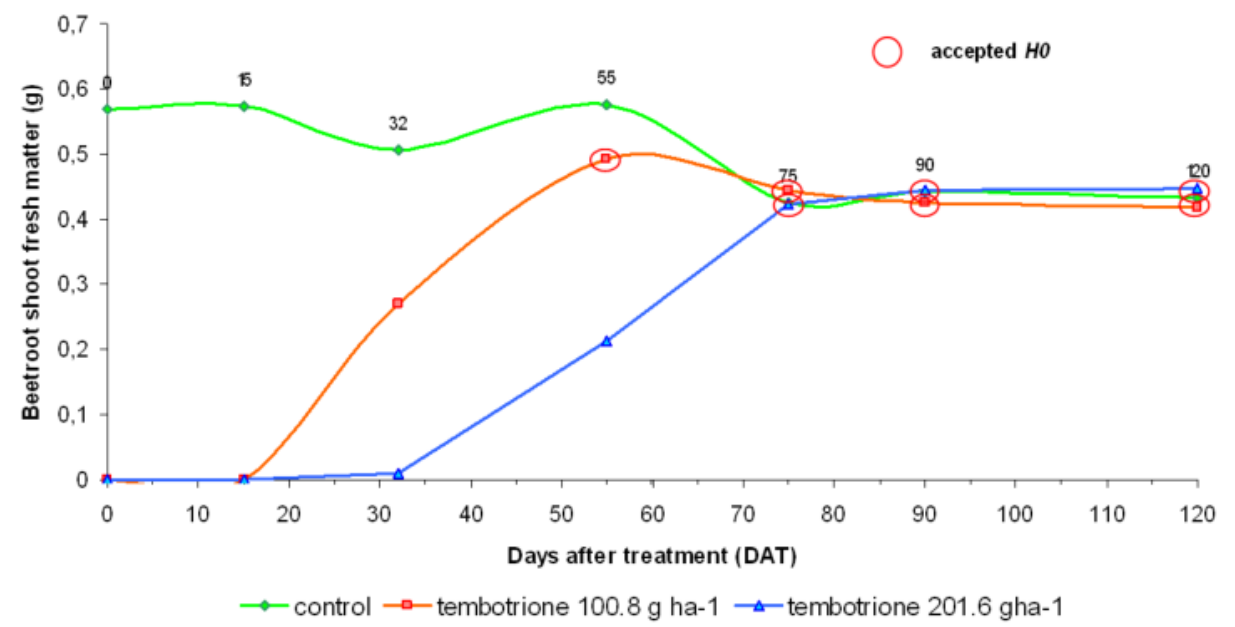

Figure 13. Residual effects of tembotrione herbicides on potted beetroot plants, used as susceptible test plants, grown under growth-chamber conditions. Data is referred to shoot fresh matter $(\mathrm{g})$ and means were compared by $\mathrm{t}$ test (0.05). [56]

The rainfall regime during the experiment (Figure 14) showed frequent and abundant rains in the period beginning, and consequently, the high soil moisture favored herbicide release in the soil solution and its subsequent rapid dissipation. This fact explains the low soil herbicide persistence - 55 and 75 DAT - obtained for the first (100.8 $\left.\mathrm{g} \mathrm{ha}^{-1}\right)$ and second doses (201.6 $\mathrm{g}$ $\left.\mathrm{ha}^{-1}\right)$, respectively. The soil moisture favorable conditions persisted until $70 \mathrm{DAT}$, almost coincident with the second rate persistence end (75 DAT).

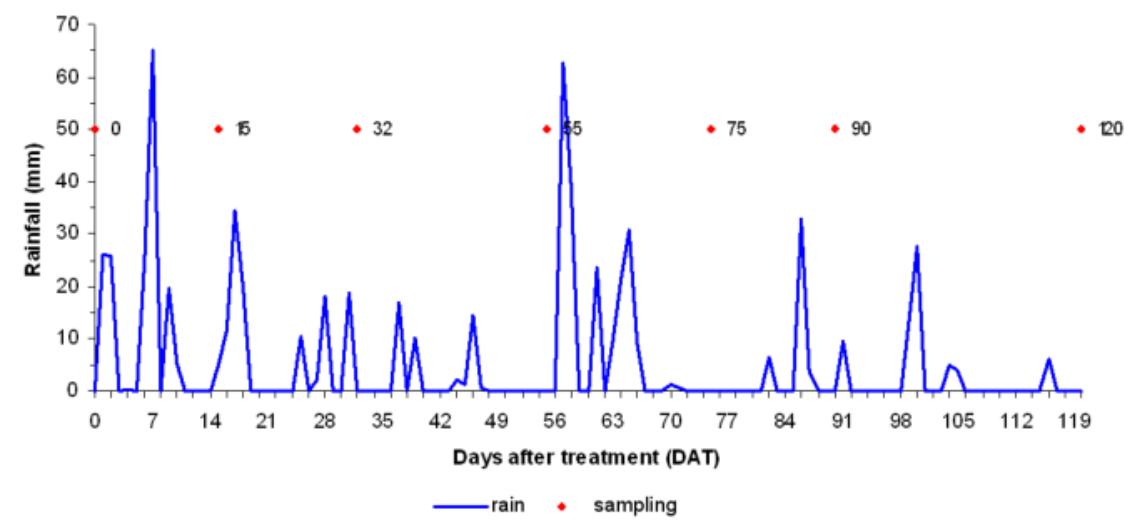

Figure 14. Rainfall regime during the experiment period described in Figure 13. [56] 
Although both experiments were carried out under "safrinha" fall conditions (dry season), the mesotrione and tembotrione persistence results (Figures 11 and 13) cannot be compared to each other, because different rainfall regimes occurred during the two field experiments (Figures 12 and 14). Therefore, a third experiment was carried out in a medium texture soil ( $\mathrm{pH} 6.6$ and $\mathrm{OM}=3 \%$ ), also under fall conditions ("safrinha" corn) as presented in Figure 15.

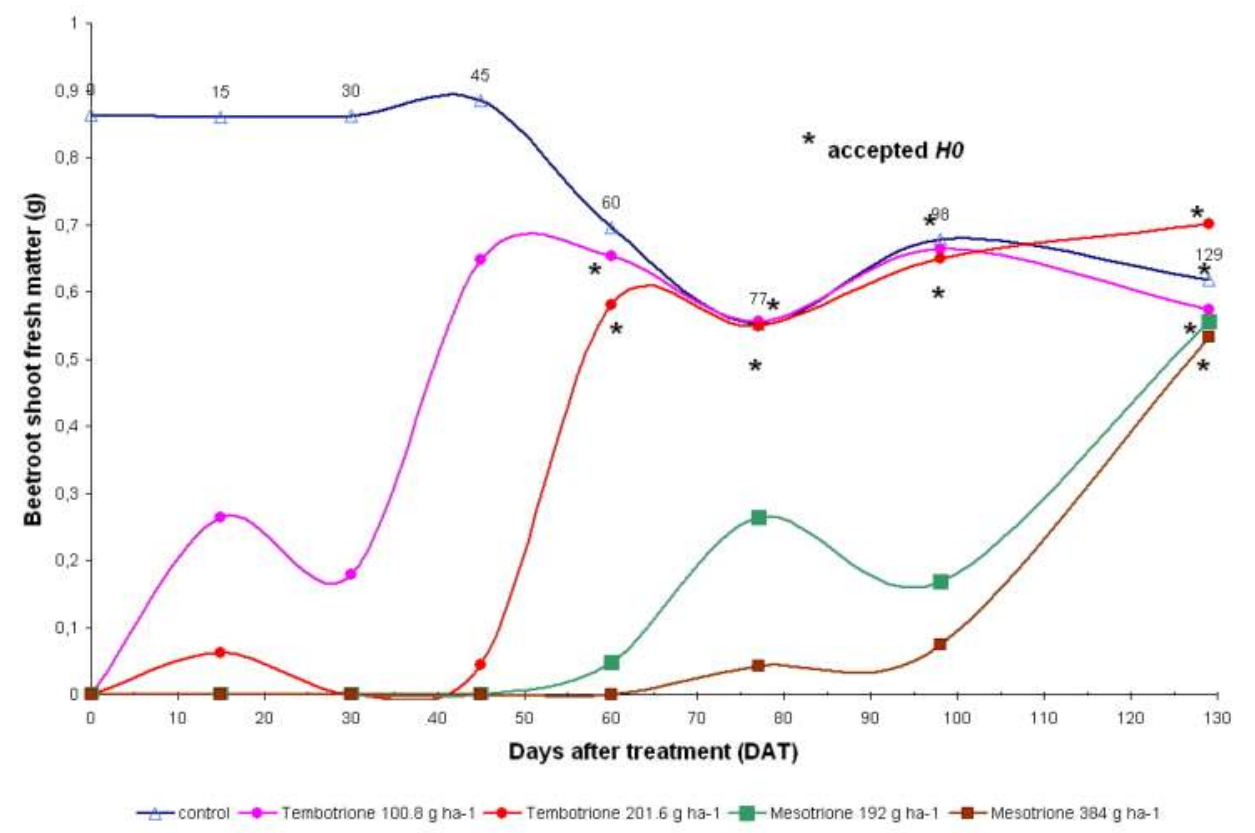

Figure 15. Residual effects of mesotrione and tembotrione herbicides on potted beetroot plants, used as susceptible test plants, grown under growth-chamber conditions. Data is referred to shoot fresh matter (g) and means were compared by $t$ test (0.05). [56].

The herbicides tembotrione and mesotrione were observed to differently affect the beetroot shoot fresh matter during the experiment time period (Figure 15).

The mesotrione residual effect of the first rate $\left(192 \mathrm{~g} \mathrm{ha}^{-1}\right)$ actually restricted the susceptible plant growth until 45 DAT, meanwhile the tembotrione residues did not restrict plant growth, except for the period 0-30 DAT at the second rate $\left(201.6 \mathrm{~g} \mathrm{ha}^{-1}\right)$. These differences were pointed out by the null hypothesis analysis (Figure 15), which indicated significant contrast differences between the control and the herbicide treatments. The analysis also indicated that tembotrione persistence ended 60 DAT and mesotrione persistence ended 129 DAT, independently of both herbicide rates.

The rainfall regime during the experiment period (Figure 16) showed that the rain volume and intensity until 75 DAT favored tembotrione dissipation that was completely depleted from soil solution $60 \mathrm{DAT}$, and from then on, did not affect beetroot plant growth (Figure 15). A dry 
period occurred from 75 to $115 \mathrm{DAT}$, which restricted mesotrione dissipation and favored its molecule sorption on soil colloids. After that period, new rainfalls caused fast mesotrione dissipation, evidenced by the persistence end 129 DAT.

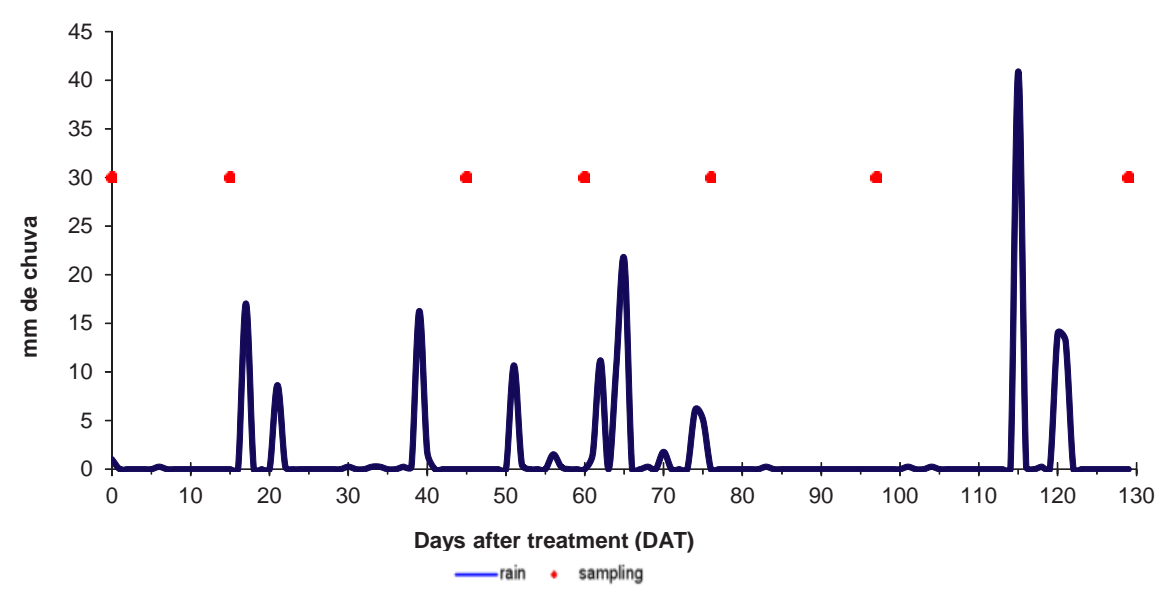

Figure 16. Rainfall regime occurred during the experiment period described in Figure 15. [56]

\section{Herbicide persistence determination under full-season cropping conditions}

Bailey \& Coffey [54] complemented the research work and carried out the same trials during the full-season maize crop, occurred during spring/summer seasons.

The results obtained with test plants grown in soil samples with residual mesotrione and tembotrione (applied to a full-season maize crop, grown in a medium texture soil, pH 5.9 and $\mathrm{OM}=2.5 \%$ ) are presented in Figure 17 .

The results indicated that beetroot plants (shoot fresh matter) grown in soil samples with tembotrione residues did not differ from the control plants $56 \mathrm{DAT}$, independently of the herbicide rate, until the end of the experiment (132 DAT). Plants grown in soil samples with mesotrione residues (first rate $=144 \mathrm{~g} \mathrm{ha}^{-1}$ ) did not differ from the control plants 83 DAT until the end of experiment (132 DAT). However, plants grown in soil samples treated with the second rate $\left(288 \mathrm{~g} \mathrm{ha}^{-1}\right)$ were severely affected, except for the last sampling period, when test plants did not show any phytotoxicity symptoms (132 DAT).

Therefore, tembotrione persistence ended 56 DAT independently of the field rate applied; mesotrione persistence ended 83 and 132 DAT for the first and second rates applied to the field (144 and $\left.288 \mathrm{~g} \mathrm{ha}^{-1}\right)$, respectively. 


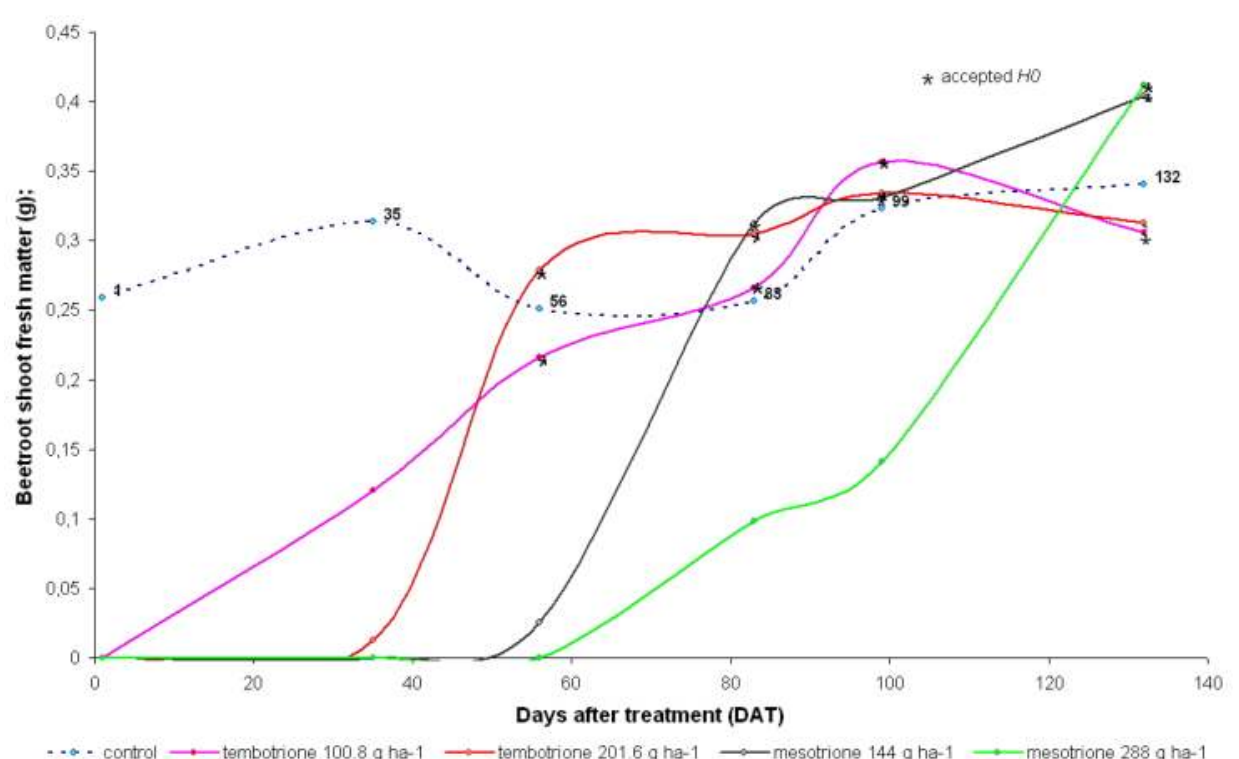

Figure 17. Residual effects of mesotrione and tembotrione herbicides on potted beetroot plants, used as susceptible test plants, grown under growth-chamber conditions. Data is referred to shoot fresh matter (g) and means were compared by t test (0.05). [56]

The rainfall regime during the experiment period (Figure 18) indicated a typical condition observed during full-season maize crop in the State of São Paulo, Brazil, with frequent and abundant rains.

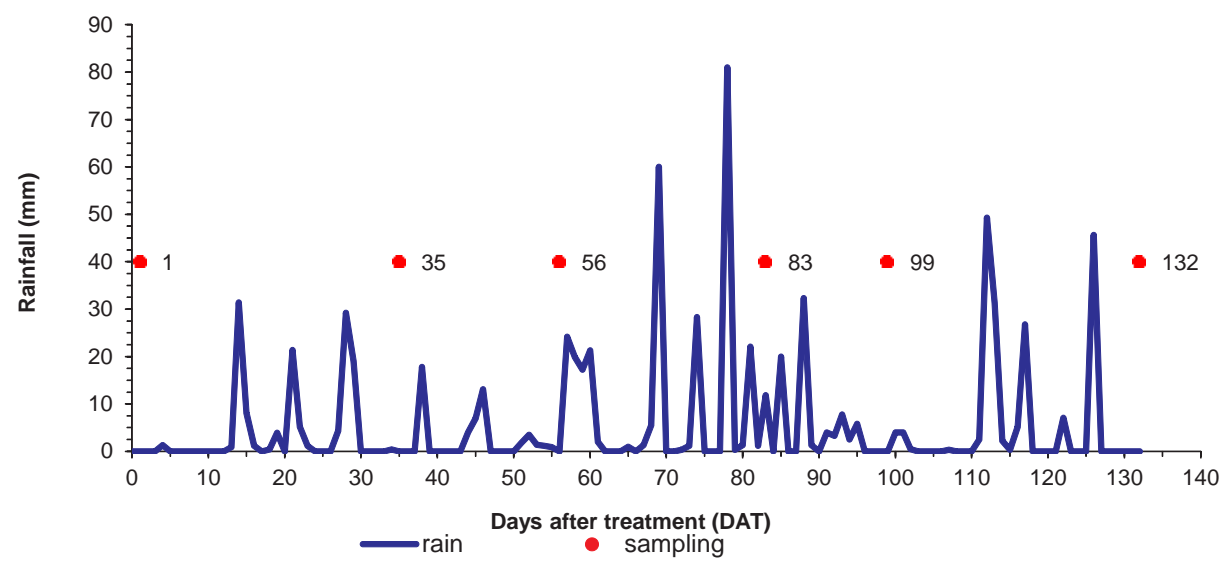

Figure 18. Rainfall regime observed during the experiment period described in Figure 17 [56]. 
The rainfall distribution favored lower herbicide sorption in soil colloids and higher availability in the soil solution, and thus, the herbicides were easily subject to biological and/or chemical dissipation processes. This explains the shorter tembotrione persistence (56 DAT). However, longer mesotrione persistence was observed (83 DAT) for the first rate (144 $\left.\mathrm{g} \mathrm{ha}^{-1}\right)$, which required one more rain period to be dissipated; and still longer (132 DAT) for the second rate $\left(288 \mathrm{~g} \mathrm{ha}^{-1}\right)$ that required even another period of rain to be dissipated.

Beetroot plants showed similar susceptibility to both herbicides, but it is possible to infer that tembotrione has a shorter persistence in the soil than mesotrione, independently of the crop season, and that tembotrione provides less environmental impact and toxicity risk to successive crops.

\section{Current scenario in Brazil}

During the human evolution process, since the beginning of agriculture 7,000 years ago, man has continuously developed technology for that activity, which nowadays, is a highly technical agriculture. However, certain facts have made us think about Carl Gustav Jung's (1875-1961) citation: "knowledge does not mean wisdom".

When mesotrione and tembotrione herbicides, among others, were released in the market, one of the main highlighted advantages at that time was the lower rates required to control weeds, which would result in significantly less environmental impact and phytotoxicity risks to crops in rotation.

Nowadays, such advantage is being revealed, because with the advent of glyphosate-resistant transgenic soybeans, the first resistant weed biotypes started to appear. Currently, there is an increasing concern about glyphosate-resistant weed biotypes after transgenic maize release, which is also resistant to glyphosate. For this reason, a glyphosate mixture with other herbicides, or else a sequential application, has been recommended justified by the need for herbicide rotation or another option to control weeds.

Actually, there has been a tendency to go back to the past with all the old misconceptions and misdirections, that is, to recommend the use of residual herbicides with high environmental impact and risk to successive crops.

It seems that it would be imperative to put in practice not only an herbicide rotation, but also a rotation between transgenic and conventional crops in order to decrease the selection pressure over weed communities, attempting to more efficiently postpone the appearance of herbicide resistant weed biotypes.

This subject will certainly be the new challenge for weed science. 


\section{Author details}

Flavio Martins Garcia Blanco, Sydnei Dionisio Batista de Almeida and Marcus Barifouse Matallo

Instituto Biológico de São Paulo, Centro Experimental, Campinas, Brazil

\section{References}

[1] Companhia Nacional de Abastecimento. CONAB: Acompanhamento da Safra Brasileira de Grãos:http://www.conab.gov.br/OlalaCMS/uploads/arquivos/ 12_08_27_09_50_57_boletim_portugues_agosto_2012.pdf (accessed 10 October 2012)

[2] Blanco, H. G.; Oliveira, D. A.; Araujo, J. B. M. Estudo sobre a competição das plantas daninhas na cultura do milho (Zea mays L.). I - Experimento para verificar onde realizar o controle do mato. Arquivos do Instituto Biológico, São Paulo 1973; 40(4) 309-320.

[3] Blanco, H. G.; Haag, H. P.; Oliveira, D. A. Estudo sobre a competição das plantas daninhas na cultura do milho (Zea mays L.). II - Influência do mato na nutrição do milho. Arquivos do Instituto Biológico São Paulo 1974; 41(1) 5-14.

[4] Blanco, H. G.; Araujo, J. B. M.; Oliveira, D. A. Estudo sobre a competição das plantas daninhas na cultura do milho (Zea mays L.). IV - Determinação do período de competição. Arquivos do Instituto Biológico, São Paulo 1976; 45(3-4) 105-114.

[5] Blanco, H. G.; Oliveira, D. A.; Araujo, J. B. M. Estudo sobre a competição das plantas daninhas na cultura do milho (Zea mays L.). III - Controle do mato em faixas sobre a linha da cultura. Arquivos do Instituto Biológico, São Paulo 1976; 43(1-2) 3-8.

[6] Sindicato Nacional da Indústria de Produtos para Defesa Agrícola. SINDAG: http:// www.sindag.com.br/noticia.php?News_ID=2256 (accessed 10 October 2012)

[7] Hanson, N. S.; Past, present, and future in the North Central Weed Control: conference. proceedings of the 4th Annual Meeting of the North Central Weed Control conference, 8-12 1947.

[8] Gianssi, L. \& N. Reigner, N. The Value of Herbicides in U.S. Crop Production, Weed Technology 2007; 21(1) 559-566.

[9] Grubinger, V. P.; Sustainable Vegetable Production From Start-Up To Market. Ithaca, NY, 1999. Cooperative Extension NRAES-104.

[10] Nalewaja, J. D. Herbicidal weed control uses energy efficiently. Weeds Today, Fall 1975. 10-12. 
[11] Esser, H.O., Dupuis, G., Ebert, E., Vogel, C., Marco, G.J. S-triazines. In: P.C. Kearney \& D.D.Kaufamn, ed. Herbicides: Chemistry, Degradation and Mode of Action, N.Y. 1975; 1(2) 129-208.

[12] Worthing, C. R. The Pestcide Manual. 7 ed. Croydon: The British Crop Council, 1983.

[13] Gast, A. Use and performance of triazines herbicides on major crops and major weeds throughout the world. Residue Rev. 1970; 32(1) 11-8.

[14] Dan Hess, F. Herbicide effects on plant structure, physiology, and biochemistry. In: Pesticide interactions in crop production. CRC Press Inc. 1993. p13-34.

[15] Walker, A. Evaluation of simulation model for prediction of herbicide movement and persistence in soil. Weed Res. 1987; 27(1) 143-152.

[16] Kearney, P. C., Sheets, P. J., Smith, J. W. Volatility of seven s-triazines. Weed 1964; 12(1) 83-7.

[17] Blanco, H. G. Destino, comportamento e resíduos de herbicidas no solo. O Biológico 1979; 45(11-12) 225-48.

[18] Briggs, G. G. Degradation in soil.In: Persistence of insecticides and herbicides. The British Crop Council 1976. 17(1) 41-54.

[19] Briggs, G. G. Molecular structure of herbicide and their sortion by soil. Nature 1969; 223(1) 288.

[20] Walker, A. The fate and significance of herbicide residue in soil. In: Scientific horticulture 1983; 34(1) 35-47.

[21] Walker, A.; Allen, J. G. Influence of soil and environmental factors on pesticide. Soil and Crop Protection Chem. 1984; 27(1) 27.

[22] Velini, E. D. Comportamento de herbicidas no solo. In: Simpósio Nacional Sobre Manejo Integrado de Plantas Daninhas em Hortaliças. FCA-UNESP, Botucatu, 1992.

[23] Harper, S. S. Sortion-desorption and herbicide behavior in soil. Rev. Weed Sci. 1994; 6(1) 207-225.

[24] Bailey, G. W., White, J. L. Factors influencing the adsorption, desorption, and movement of pesticides in soil. Residue Rev. 1970; 32(1) 29-92.

[25] Hayes, M. H. B Adsorption of triazine herbicides on soil organic matter, including a short review on soil organic matter chemistry. Residue Reviews 1970; 32(1) 131-174.

[26] Weber, J. B., Weed, J. B., Ward, T. M. Adsorption of s-triazines by soil organic matter. Weed Sci. 1969; 17(1) 417-421.

[27] Weber, J. B. Mechanism of adsorption of s-triazines by clay colloids and factors affecting plant availability. Residue Rev. 1970; 32(1) 93-130. 
[28] Walker, A. \& Brown, P.A. The relative persistence in soil of acetanilide herbicides. Bull. Environ. Contam. Toxicol. 1985; 134(1) 143-149.

[29] Riley, D. Physical loss and redistribution of pesticides in the liquid phase. The British Crop Protection Council 1978; 17(1) 109-116.

[30] Helling, G.S. Movement of s-triazine herbicides in soils. Residue Reviews 1970; 32(1) 175-210.

[31] Blanco, F. M. G.; Velini E. D.; Batista Filho, A. Persistence of Herbicide Sulfentrazone in Soil Cultivated with Sugarcane and Soy and Effect on Crop Rotation, Herbicides Properties, Synthesis and Control of Weeds, Mohammed Naguib Abd El-Ghany Hasaneen (Ed.), ISBN:978-953-307-803-8,InTech;2012.Availablefrom: http:// www.intechopen.com/books/herbicides-properties-synthesis-and-control-of-weeds/ persistence-of-herbicide-sulfentrazone-in-soil-cultivated-with-sugarcane-and-soyand-effect-on-crop-

[32] Kenaka, E. E. Evaluation of the harzard of pesticides residues in the environment. In: Watson, D. L., Brown, A. W. A. (ed) Pesticides management and insecticides resistance. New York: Academic Press 1977. p51-95.

[33] Spalding, R. F., Burbach, M. E., Exner, M. E. Pesticides in Nebraska's ground water. Grond Water Monitoring Rev. 1989; 9(4) p126-133.

[34] Cerdeira, A.L.; Santos, N. A. G.; Ueta, J.; Shuhama, I. K.; Pessoa, M.C.P.Y.; Smith JR, S.; Lanchote, V. L. Atrazine in Water and Biodegradation in a Recharge Area of Guarany Aquifer in Brazil. Bulletin of Environmental Contamination and Toxicology 2004; 73(1) 117-124.

[35] Almeida, S.D.B.; Costa, E.; Gomes, M.A.F.; Luchini, L.; Spadotto, C.; Matallo, M. B.Sorção de Triazinas em Solos Tropicais. I. Pré seleção para recomendação de uso na região de Ubatuba, São Paulo, Brasil. In: IV Congreso Iberoamericano de Física Y Química Ambiental 2006, Cáceres. MEDIOAMBIENTE EN IBEROAMERICA - Visión desde la Física y La Química en los albores del siglo XXI 2006. 2(1) 17-24.

[36] Piccolo, A. \& Conte, P.. Advances in nuclear magnetic resonance and infrared spectroscopies of soil organic particles. In: Structure and Surface Reactions of Soil Particles (eds P.M. Huang, N. Senesi \& J. Buffle), Wiley-Interscience, New York, 1998, p375-435.

[37] Blanco, F. M. G.; Blanco, H. G.; Machado, T. R. Persistência e lixiviação do herbicida simazine em solo barrento cultivado com milho. Planta Daninha, 1997; 15(1) 130-140.

[38] Bouchet, F. Estude de l'influence de la nature du sol sur l'action herbicide de la simazine. Weed Res. 1967; 7(1) 102-116.

[39] Burnside, O. C.; Fenster, C. R.; Wicks, G. A. Dissipation and leaching of monuron, simazine, and atrazine in Nebraska soils. Weed 1963; 11(1) 209-213. 
[40] Clay. D.V., Mckone, C.E. The persistence of chlorthiamid, lenacil and simazine in uncropped soil. British Weed Control Conference, 9, Brigthon, England 1968. Proceedings; 2(1) 933-938.

[41] Dawson, J.H., Bruns, V.F., Clore, W.J. Residual monuron, diuron and simazine in a vineyard soil. Weed Sci. 1968; 16(1) 63-65.

[42] Kozlowski, T.T., Kuntz, J.E. Effects of simazine, atrazine, propazine, and Eptan on growth and developement of pine seedlings. Soil Sci. 1963; 95(1) 164.

[43] Kozaczenko, H. Factores affecting the efficiency of herbicides. Biul. Warzyw. 8 (31). 1965. Apud. Weed Abstracts, 1966; 15 (1), 1780 p.

[44] Sheets, T.J. The comparative toxicities of monuron and simazine in soil. Weeds 1959; 7(1) 189-219.

[45] Briggs, G.G. Theoretical and experimental relationships between soil adsorption, octanol - water partition coefficients, water solubilities, bioconcentration factors, and the parachor. J. Agric. Food Chem. 1981; 29(1) 1050-1059.

[46] Briggs, G.G. Factors affecting the uptake of soil-applied chemicals by plants and other organisms., Proceedings, symposium on soil and crop protection chemicals 1984; p35-47.

[47] Blanco, F. M. G.; Machado, T. R. Persistence and leaching of atrazine and metolachlor in soil under corn. In: Third International Weed Science Congress. Fox do Iguassu, 2000, Abstrats, p 90.

[48] Frank, R. \& Sirons, G. J. Dissipation of atrazine residues from soils. Bulletin of Environmental Contamination and Toxicology 1985; 34(4) 541-48.

[49] Durand, G. \& Barcelo, D. Environmental degradation of atrazine, linuron and fenitrothion in soil samples. Toxicological and Environmental Chemistry 1992; 36(3-4) 225-34.

[50] Zindahl, R. L. \& Clark, S. K. Degradation of three acetanilide herbicides in soils. Weed Sci. 1982; 30(1) 545-548.

[51] Beestman, G. B. \& Deming, J. M. Dissipation of acetanilide herbicides from soil. Agron. J. 1974; 66(1) 308-311.

[52] Mcgahen, L. L. \& Tidge, J. M. Metabolism of two new acetanilide herbicides, Antor herbicides (H-22234) and Dual (metolachlor) by the soils fungus Chaetomiun globosum. J. Agric. Food Chem. 1978; 26(1) 414-419.

[53] Dermont, C. B.; Lavy, T. L.; Marx, D. B. Rate of metribuzin, metolachlor and fluometron in soil. Weed Sci. 1982; 30(1) 629-632. 
[54] Bailey, A. M. \& Coffey, M. D. Characterization of microorganisms involved in accelerated biodegradation of metalaxyl and metolachlor in soils. Can. J. Microbiol. 1986; 32(1) 562-569.

[55] Peter, C. J. \& Weber, J. B. Adsorption, mobility and efficacy of alachlor and metolachlor as influenced by soil properties. Weed Sci. 1985; 33(1) 874-81.

[56] Blanco, F. M. G.; Franco, G. V.; Ramos, Y. G. Persistência dos herbicidas Tembotrione, mesotrione e atrazina aplicados na cultura do milho. In: 27ํㅡㄹ Congresso Brasileiro da Ciência das plantas daninhas. Ribeirão Preto, SP, 2010. p1738-1742 
